Research Article

\title{
Antimalarial, Antioxidant, and Toxicological Evaluation of Extracts of Celtis africana, Grosseria vignei, Physalis micrantha, and Stachytarpheta angustifolia
}

\author{
Michael Konney Laryea ${ }^{1}$ and Lawrence Sheringham Borquaye $\mathbb{D}^{1,2}$ \\ ${ }^{1}$ Department of Chemistry, Kwame Nkrumah University of Science and Technology, Kumasi, Ghana \\ ${ }^{2}$ Central Laboratory, Kwame Nkrumah University of Science and Technology, Kumasi, Ghana \\ Correspondence should be addressed to Lawrence Sheringham Borquaye; lsborquaye.sci@knust.edu.gh
}

Received 13 March 2021; Revised 29 May 2021; Accepted 16 June 2021; Published 23 June 2021

Academic Editor: Jayanta Kumar Patra

Copyright (c) 2021 Michael Konney Laryea and Lawrence Sheringham Borquaye. This is an open access article distributed under the Creative Commons Attribution License, which permits unrestricted use, distribution, and reproduction in any medium, provided the original work is properly cited.

\begin{abstract}
In many parts of the world, malaria undoubtedly poses a serious threat to health care systems. Malaria treatment has increasingly become complicated, primarily due to the emergence of widespread resistance of the malaria parasites to cheap and affordable malaria therapeutics. The use of herbal remedies to treat various ailments, including malaria and malaria-like ailments in Ghana is common. We herein report on the antiplasmodial and antioxidant activities as well as toxicological evaluation of four medicinal plants (Celtis africana, Grosseria vignei, Physalis micrantha, and Stachytarpheta angustifolia) commonly used to treat malaria in Ghana. Following Soxhlet extraction of plant samples in ethanol, extracts were screened against Plasmodium falciparum (3D7 strain) in an in vitro antiplasmodial assay. The phosphomolybdenum and DPPH (1,1-diphenyl-2 picrylhydrazyl) assays were used to evaluate antioxidant activities while toxicity assessment was carried out in mice using the acute toxicity test and kidney and liver function tests. Extracts from Celtis africana and Physalis micrantha were very active towards the parasites with half-maximal inhibitory concentrations $\left(\mathrm{IC}_{50}\right.$ 's) of 29.1 and $3.5 \mu \mathrm{g} / \mathrm{mL}$, respectively. Extracts of Grosseria vignei and Stachytarpheta angustifolia were inactive, having $\mathrm{IC}_{50}$ values greater than $50 \mu \mathrm{g} / \mathrm{mL}$. All extracts exhibited excellent total antioxidant capacities $(>800 \mathrm{mg} / \mathrm{g}$ $\mathrm{AAE}$ ) and good DPPH radical scavenging potential $\left(\mathrm{IC}_{50}\right.$ range of $\left.300-900 \mu \mathrm{g} / \mathrm{mL}\right)$. The median lethal dose $\left(\mathrm{LD}_{50}\right)$ of all extracts in the toxicological evaluation was greater than $2000 \mathrm{mg} / \mathrm{kg}$ and there was no effect of extracts on the levels and activities of key biomarkers of liver and kidney function. The activities of these plants obtained in this study partly give credence to their folkloric use in herbal medicines and suggest that they could provide promising lead compounds for malaria drug discovery programs.
\end{abstract}

\section{Introduction}

In many countries in Sub-Saharan Africa, malaria remains a leading cause of mortality and morbidity among the populace, with detrimental effects on health care programs in these countries. The economic impact is disheartening. Despite numerous efforts and interventions put in place to combat the disease globally, the World Health Organization (WHO) reported in 2018 that malaria is still endemic in 80 countries and territories. This number has only been reduced from 108 since the year 2000 [1]. Various interventions have been developed for both vector and parasites to curb malaria infection in humans. The use of mosquito repellent sprays and creams and mosquito insecticide nets are some strategies commonly used to control the malaria vector [2]. Various drugs, either alone or in combination, have also been developed for use as curative or prophylactic interventions. Currently, artemisinin-based combination therapies are used for treating uncomplicated malaria in both children and adults [3]. The recent development of a malaria vaccine increases the artillery available to man in this war against malaria $[4,5]$. However, reports of resistance to some drugs by the parasites have presented formidable challenges that need to be addressed for success $[6,7]$.

Oxidative stress has been suggested to play an important role in malaria pathology. Red blood cells infected with the 
Plasmodium parasite must eliminate reactive oxygen species (ROSs) produced during malaria infection to maintain cellular integrity. Large quantities of redox-active species are produced during metabolism in the fast-growing and multiplying parasite. These redox-active compounds are used by the parasite to break down host hemoglobin. Degradation of hemoglobin produces toxic free haem (ferri/ ferroprotoporphyrin IX-FP) and ROSs, amongst others. A number of pathways exist for FP detoxification-sequestration into a crystalline haemozoin, FP degradation, reaction of FP with glutathione, and binding of FP to FPbinding proteins [8-11]. The presence of FP in the host cell could cause devastating redox damage to membranes and proteins in the host cell and lyse red blood cells [12]. Additionally, ROSs are produced by the host immune system during malaria infection and together contribute substantially to oxidative stress in the infected cell. The important role of oxidative stress in malaria pathology provides a promising target in antimalarial chemotherapy development [13]. The need to unearth newer, more potent therapeutic agents is great at the moment.

Traditional herbal preparations provide a useful avenue to prospect for therapeutic agents that are potent against the Plasmodium parasite. In Africa and many parts of Asia and the Americas, plant-based preparations are commonly used to treat various conditions, including malaria and malarialike symptoms. The WHO estimates that over $70 \%$ of the population in Africa rely on herbal-based preparations for their health care needs [14]. A majority of compounds historically important in the fight against malaria have been derived from plants or modeled on structures derived from lead compounds isolated from plants. Examples of these include quinolone-based malaria drugs such as quinine and chloroquine as well as artemisinin and its derivatives [15]. The therapeutic success of these compounds has inspired the search for new antimalarial compounds from plant sources. A major challenge in the development of herbal medicine is the absence of toxicity data on the plant products administered [16]. Reports of adverse effects associated with the consumption of plant medicines necessitate a rigorous evaluation of the safety of potential plant products [17].

In Ghana, various medicinal plants are used in managing malaria and symptoms of malaria [18]. Many of these plants have not, however, been verified scientifically as possessing antiplasmodial activities. This work, therefore, seeks to validate the antiplasmodial properties of some plants commonly used to treat malaria in Ghana. The plants were selected from a survey of medicinal plants used in the country. Due to the important role of oxidative stress in malaria pathology, the antioxidant activities of the plants were also assessed. Finally, the effect of the plant extracts on some toxicological markers in a murine model was also investigated. We herein report on the antiplasmodial, antioxidant, and toxicological profile of the ethanolic extracts of Celtis africana, Grosseria vignei, Physalis micrantha, and Stachytarpheta angustifolia.

\section{Methods}

\subsection{Plant Material Preparation}

2.1.1. Collection and Authentication of Plant Materials. The plant samples, Celtis africana, Grosseria vignei, Physalis micrantha, and Stachytarpheta angustifolia, were collected from Kwahu Asakraka, $\left(6^{\circ} 38^{\prime} 05.2^{\prime \prime} \mathrm{N} 0^{\circ} 41^{\prime} 20.6^{\prime \prime} \mathrm{W}\right)$ in the Eastern Region of Ghana. Sample collection was done between July and September 2018 with the help of a plant botanist, Mr. Clifford Asare of the Department of Herbal medicine, Faculty of Pharmacy and Pharmaceutical Sciences at the Kwame Nkrumah University of Science and Technology (KNUST). After collection, foreign materials were removed from the plant materials and washed under running water. These were then allowed to dry in air at ambient temperatures under a shade for up to 30 days. The dried plant material was cut into small pieces and milled into a course powder. Plant part used, families, local names, and indications of the selected plants used for the study have been described in Table 1.

2.1.2. Extraction. To $100 \mathrm{~g}$ of the plant material, $500 \mathrm{~mL}$ of $99 \%$ ethanol was used for Soxhlet extraction for a minimum duration of 4 hours. The extract was then filtered to separate any residue from the menstruum. The filtrate was then concentrated in vacuo (Cole Parmer Rotary Evaporator $\mathrm{N}-1110$, China) to dryness and transferred into screwcapped amber vials and stored below $4^{\circ} \mathrm{C}$ until it was ready for use.

2.2. Phytochemical Screening. The presence or absence of various phytochemicals-flavonoids, alkaloids, tannins, sterols, glycosides, and coumarins-were tested in the plant extracts by following standard procedures $[19,20]$.

2.3. In vitro Antiplasmodial Assay. For this assay, a chloroquine-sensitive Plasmodium falciparum 3D7 strain was used. The Plasmodium parasite was added to freshly prepared human erythrocytes $\left(\mathrm{O}^{+}\right)$that were suspended in complete RPMI-1640 parasite medium enhanced with $10 \%$ normal human serum and then gassed with a gas mixture $\left(2 \% \mathrm{O}_{2}, 5.5 \% \mathrm{CO}_{2}\right.$, and $92.5 \% \mathrm{~N}_{2}$-Air Liquide, UK). The parasite culture was incubated (RS Biotech, USA) at $37^{\circ} \mathrm{C}$ and maintained daily by changing the media. Stock solutions of the plant extracts were made in $70 \%$ ethanol. Dilution of the stock solutions yielded working solutions with concentrations between $0.5 \mu \mathrm{g} / \mathrm{mL}$ and $600 \mu \mathrm{g} / \mathrm{mL}$ which was used for the assay. Synchronization of the Plasmodium culture was made with $5 \%$ sorbitol to obtain the ring stage of the parasite, which was used in the assay. Working solutions of the synchronized parasites were prepared in a complete medium. In a flat-bottom 96-well microtiter plate containing $50 \mu \mathrm{L}$ of plant extract, $1.5 \%$ cell suspension of parasitized erythrocytes (about $0.9-1.5 \%$ parasitemia) was added. 
TABLE 1: Botanical name, family, local name, part used, and local indication of selected plants.

\begin{tabular}{|c|c|c|c|c|}
\hline Botanical name & Family & Local name (Twi) & $\begin{array}{c}\text { Plant part used (voucher specimen } \\
\text { number) }\end{array}$ & Local indications \\
\hline Celtis africana & Cannabaceae & Essa & $\begin{array}{c}\text { Stem bark (KNUST/HMI/2021/SB011) } \\
\text { Leaves (KNUST/HMI/2021/L006)T }\end{array}$ & Fever/headache/sore \\
\hline Grosseria vignei & Euphorbiaceae & Dubrafor & $\begin{array}{l}\text { wigs (KNUST/ } \\
\text { HMI/2021/T001) }\end{array}$ & Wound healing/fever \\
\hline Physalis micrantha & Colanaceae & Toto nini & $\begin{array}{c}\text { Leaves }(\mathrm{KNUST} / \mathrm{HMI} / 2021 / \mathrm{L} 007) \mathrm{T} \\
\text { wigs }(\mathrm{KNUST} / \\
\mathrm{HMI} / 2021 / \mathrm{T} 002)\end{array}$ & Malaria/painkiller/epilepsy \\
\hline $\begin{array}{l}\text { Stachytarpheta } \\
\text { angustifolia }\end{array}$ & Verbenaceae & Kwankurahu & $\begin{array}{c}\text { Leaves }(\mathrm{KNUST} / \mathrm{HMI} / 2021 / \mathrm{L} 008) \mathrm{T} \\
\text { wigs }(\mathrm{KNUST} / \\
\mathrm{HMI} / 2021 / \mathrm{T} 003)\end{array}$ & $\begin{array}{l}\text { Venereal diseases/dropsy/ } \\
\text { fever }\end{array}$ \\
\hline
\end{tabular}

Artemisinin was used as a standard drug and treated similarly to the extracts. Solvent controls were also included. Microtiter plates were gassed in a desiccator with a gas mixture of $2 \% \mathrm{O}_{2}, 5.5 \% \mathrm{CO}_{2}$, and $92.5 \% \mathrm{~N}_{2}$. The reaction mixture was incubated at $37^{\circ} \mathrm{C}$ for 72 hours. Upon assay termination, thin smears were made on glass slides from each duplicated well, fixed in methanol, and then dried. The slides were stained with Giemsa stain (Fluka Chemicals, UK), washed, dried, and examined using 100x magnification oil immersion objective lens of light microscope (Leica 1349522X, USA). The number of infected RBCs in a given grid area was counted. For each slide, a minimum of 1000 RBCs were counted $[19,21,22]$. The percentage of parasitemia was computed using the following expression:

$$
\% \text { parasitemia }=\frac{\text { number of infected } \mathrm{RBCs}}{\text { total number of } \mathrm{RBCs}} \times 100 .
$$

Dose-response curves were plotted and used to compute half-maximal inhibitory concentrations $\left(\mathrm{IC}_{50}\right)$. Microsoft Excel and GraphPad Prism were used for all data and statistical analysis. All experiments were performed in triplicate.

\subsection{Antioxidant Assays}

2.4.1. DPPH Radical Scavenging Assay. The 2, 2-diphenyl-1picrylhydrazyl (DPPH) free radical scavenging method was used in estimating the radical scavenging activity of the extracts. A $0.1 \mathrm{mM}$ solution of DPPH in methanol was prepared and introduced into wells in a microtiter plate. To each of the wells, $100 \mu \mathrm{L}$ of each varying concentration of extract prepared in methanol was added and mixed. The mixture was then incubated in the dark for $30 \mathrm{~min}$. Absorbance was taken at $517 \mathrm{~nm}$ (Multimode Microplate Reader, BioTek Synergy H1, Germany). A methanol control blank was made and ascorbic acid was used as a standard drug. All tests were conducted as triplicates on the microtiter plate. Percentage of DPPH radical scavenged was calculated as follows:

$$
\% \mathrm{DPPH} \text { radical scavenged }=\left(\frac{\mathrm{Ac}-\mathrm{As}}{\mathrm{Ac}}\right) \times 100,
$$

where $A c$ represents the absorbance of control and $A s$ represents the absorbance of each test sample. The DPPH radical scavenging activity was reported as $\mathrm{IC}_{50}$ 's from a dose-response curve which was obtained by plotting $\%$ $\mathrm{DPPH}$ radical scavenged against extract concentration [23].

2.4.2. Total Antioxidant Capacity. The phosphomolybdenum (PM) method was used to estimate the total antioxidant capacity. The PM reagent was prepared by adding $2 \mathrm{~mL}$ each of $0.6 \mathrm{M}$ sulfuric acid, $28 \mathrm{mM}$ sodium phosphate, and $4 \mathrm{mM}$ ammonium molybdate to $94 \mathrm{~mL}$ of distilled water. To $0.1 \mathrm{~mL}$ of each sample solution, (various concentrations) $1 \mathrm{~mL}$ of the $\mathrm{PM}$ reagent was added. The mixture was then capped and incubated in a water bath at $90^{\circ} \mathrm{C}$ for $90 \mathrm{~min}$. After cooling to room temperature, absorbance was measured at $695 \mathrm{~nm}$ (Shimadzu UV-1280 UV-Vis Spectrophotometer, Japan) against a blank. The blank solution contained $1 \mathrm{ml}$ of the PM reagent solution and 0.1 of distilled water and incubated under the same conditions as the test samples. Ascorbic acid was used as standard and was used in the generation of a calibration curve. All tests were conducted in triplicate. The total antioxidant capacity was expressed in ascorbic acid equivalents (mg/g AAE) [23].

2.4.3. Total Phenolic Content. Folin and Ciocalteu's method was used in the assessment of total phenolic content (TPC). Different concentrations of the extracts were made in methanol. The reaction mixture contained an aliquot of each sample $(0.5 \mathrm{~mL}), 10 \%$ Folin-Ciocalteu's reagent $(2.5 \mathrm{~mL})$, and $7.5 \%$ sodium carbonate $(2 \mathrm{~mL})$. This was then made to stand for $30 \mathrm{~min}$ at room temperature before absorbance readings at $760 \mathrm{~nm}$ (Shimadzu UV-1280 UV-Vis Spectrophotometer, Japan). Gallic acid was used as a standard and was used in generating a calibration curve. All experiments were conducted in triplicate. The TPC was expressed in gallic acid equivalents (mg/g GAE) [23].

\subsection{Toxicological Evaluation}

2.5.1. Acute Toxicity. Experiments were conducted according to the Organization for Economic Cooperation and Development (OECD) guidelines for testing of chemicals' acute oral toxicity [24]. The acute toxicity of the extracts was assessed in female Balb/C mice, aged 8-10 weeks (20-40 g body weight). Five groups of 5 animals were used in 
the study. Prior to the experiment, all animals in the various groups were kept in their respective cages for 7 days for acclimatization under a 12 hour dark/light cycle. Food and water were freely available. Groups 1 to 4 received extracts whereas group 5 received vehicle only (saline). Animals in groups 1-4 received plant extract at a fixed dose of $2000 \mathrm{mg} /$ $\mathrm{kg}$. The animals were observed immediately after extract or saline administration; at 30 minutes, 60 minutes, 4 hours, and 24 hours after administration; and then once a day for the next 14 days for signs of behavioral changes (changes in hair, eyes, skin, mucous membrane, salivation, lethargy, diarrhea, and sleep) or mortality. Feed and water consumption were monitored. Body weights were recorded on days 7 and 14 [25].

2.5.2. Serum Analysis. Mice were anesthetized on day 15 and blood samples were collected from their chest cavity into gel tubes with no anticoagulants. Blood samples were then centrifuged at $3000 \mathrm{rpm}$ for 10 minutes to obtain the serum. The obtained serum was stored at $4^{\circ} \mathrm{C}$ for the evaluation of biochemical parameters-aspartate transaminase, alanine transaminase, alkaline phosphatase, total bilirubin, direct bilirubin, indirect bilirubin, albumin, globulin, total protein, creatinine, and urea. The evaluation of the biochemical parameters for kidney and liver functions was done on an Automated Clinical Chemistry Analyzer (Le Scientific Medfuture LCC, USA) using commercially available kits (Anamol Laboratories Pvt. Ltd., India) [19].

\section{Results}

Four plants commonly used in folkloric medicine in Ghana for the treatment of malaria and malaria-like symptoms were selected for this study. The stem bark, leaves, and twigs of the plants are mostly used in herbal medicine and so these parts were employed here. Table 1 provides the botanical name, family, local name, plant part used, and local indication of selected plants used in the study. Extraction of plant materials by Soxhlet gave the products in appreciable yields, as seen in Table 2. The yield was in the order Celtis africa$n a>$ Grosseria vignei $>$ Stachytarpheta angustifolia $>$ Physalis micrantha. The selected plants were evaluated for the presence or absence of 6 common phytochemicals: flavonoids, alkaloids, tannins, sterols, glycosides, and coumarins, and the results are presented in Table 3. All selected plants tested positive for the presence of tannins whereas none tested positive for the presence of alkaloids. Celtis africana did not give a positive test for flavonoids whereas Stachytarpheta angustifolia is the only plant that gave a positive result for the presence of glycosides.

Using the classification standards of Jonville et al. [26], the antiplasmodial activity against Plasmodium falciparum 3D7 strain was classified (Table 2). Physalis micrantha had the best antiplasmodial activity with an $\mathrm{IC}_{50}$ value of $3.51 \pm 0.19 \mu \mathrm{g} / \mathrm{mL}$. Celtis africana had a moderate antiplasmodial activity with an $\mathrm{IC}_{50}$ value of $29.05 \pm 1.29 \mu \mathrm{g} /$ $\mathrm{mL}$. Grosseria vignei and Stachytarpheta angustifolia were classified as inactive with $\mathrm{IC}_{50}$ values greater than $50 \mu \mathrm{g} /$
$\mathrm{mL}$. The standard drug, artemisinin, recorded an $\mathrm{IC}_{50}$ of $0.014 \pm 0.001 \mu \mathrm{g} / \mathrm{mL}$. Table 4 shows the results for the total antioxidant capacity, radical scavenging ability, and total phenolic content of the plant extracts. The total antioxidant capacities of the selected plant extracts were within the ranges of 800 to $840 \mathrm{mg} / \mathrm{g} \mathrm{AAE}$, indicating very good activities. Stachytarpheta angustifolia extract exhibited the best total antioxidant capacity of about $836.8 \pm 5.57 \mathrm{mg} / \mathrm{g}$ AAE. This was followed by extracts of Celtis africana and Grosseria vignei. Extract of Physalis micrantha exhibited the lowest TAC. In the DPPH radical scavenging activity, $\mathrm{IC}_{50}$ values obtained ranged between 395 and $906 \mu \mathrm{g} / \mathrm{mL}$ for 4 plant extracts. Physalis micrantha had the best DPPH scavenging activity with an $\mathrm{IC}_{50}$ value of $395 \pm 7.90 \mu \mathrm{g} / \mathrm{mL}$. In comparison, the standard ascorbic acid standard had an IC $_{50}$ of $36.34 \pm 1.06 \mu \mathrm{g} / \mathrm{mL}$. The order of activity in the $\mathrm{DPPH}$ radical scavenging assay was Physalis micrantha $>$ Celtis africana $>$ Stachytarpheta angustifolia $>$ Grosseria vignei. There was a direct correlation between antiplasmodial activity and antioxidant activity, with the same order of activity of plant extracts observed in both assays. Due to the role of phenolic compounds as potential antioxidants, the total phenolic content (TPC) of the extracts was also investigated. TPC values ranged between 15 and $109 \mathrm{mg} / \mathrm{g}$ GAE. Grosseria vignei recorded the highest TPC, with Physalis micrantha having the lowest. There was no direct correlation between DPPH activity and TPC in this study.

In the acute toxicity test, mice were dosed with a fixed amount of extract or saline and the mice were studied over a 14-day period. The clinical appearance of all mice in the various groups, including the control group, did not show any treatment-related adverse effects. No deaths were recorded in any of the groups and all morphological and behavioral observations were normal. Body weight monitoring over the period of the study revealed a gradual increase in weight in mice as seen in Figure 1. In the control group, an average weight increase of $9.38 \%$ was observed after 14 days. Groups that received Physalis micrantha, Celtis africana, Stachytarpheta angustifolia, and Grosseria vignei recorded body weight increases of $6.44,5.43,-1.15$, and $14.73 \%$, respectively, between days 1 and 14 . The halfmaximal lethal dose $\left(\mathrm{LD}_{50}\right)$ for all extracts was estimated to be over $2000 \mathrm{mg} / \mathrm{kg}$.

The activities of various enzymes in blood drawn on day 15 from animals in the various treatment groups were used as markers for the hepatic and renal status of animals after extract treatment. For hepatic function, activities that corresponded to aspartate transaminase, alanine transaminase, alkaline phosphatase, total bilirubin, direct bilirubin, indirect bilirubin, albumin, globulin, and total protein were determined (Figure 2). The levels of these markers in animals in the control group and the extract-treatment groups showed no significant statistical differences $(p>0.05)$. For kidney function, the levels of urea and creatinine were used as markers and the results are shown in Figure 3. Similar to the results in the liver function test, no significant differences were observed between animals in the extract-treatment groups and the control groups. 
TABLE 2: Extract yield and in vitro antiplasmodial activity of selected plants against Plasmodium falciparum 3D7 strain.

\begin{tabular}{lccc}
\hline Plant extract & Extract yield* $(\%)$ & Antiplasmodial activity- $\mathrm{IC}_{50}(\mu \mathrm{g} / \mathrm{ml})$ & Classification $^{* *}$ \\
\hline Celtis africana & 15.2 & $29.05 \pm 1.29$ & Moderate \\
Grosseria vignei & 7.3 & $>50$ & Inactive \\
Physalis micrantha & 5.4 & $3.51 \pm 0.19$ & High \\
Stachytarpheta angustifolia & 5.7 & $>50$ & Inactive \\
Artemisinin & NA & $0.014 \pm 0.001$ & NA \\
\hline
\end{tabular}

NA - not applicable. ${ }^{*}$ Extract yield percentage based on dry pulverized plant material. ${ }^{* *}$ Classification of antiplasmodial activity based on [26] - high ( $\left.\mathrm{IC}_{50}<5 \mu \mathrm{g} / \mathrm{mL}\right)$, promising $\left(5<\mathrm{IC}_{50}<15 \mu \mathrm{g} / \mathrm{mL}\right)$, moderate $\left(15<\mathrm{IC}_{50}<50 \mu \mathrm{g} / \mathrm{mL}\right)$, and inactive $\left(\mathrm{IC}_{50}>50 \mu \mathrm{g} / \mathrm{mL}\right)$.

TABle 3: Phytochemical composition of selected plants.

\begin{tabular}{lcccccc}
\hline Plant extract & Flavonoids & Alkaloids & Tannins & Sterols & Glycosides & Coumarins \\
\hline Celtis africana & + & - & ++ & - & - & - \\
Grosseria vignei & ++ & - & ++ & - & - & - \\
Physalis micrantha & + & - & ++ & - & + \\
Stachytarpheta angustifolia & ++ & - & ++ & ++ & + \\
\hline
\end{tabular}

(-)—not detected; (+)—present; (++)—strongly present.

TABLE 4: Antioxidant capacity, radical scavenging, and total phenolic content of selected plants.

\begin{tabular}{lccc}
\hline Plant extract & $\begin{array}{c}\text { Antioxidant capacity mg/g } \\
\text { (AAE) }\end{array}$ & $\begin{array}{c}\text { DPPH radical scavenging } \text { IC }_{50} \\
(\mu \mathrm{g} / \mathrm{mL})\end{array}$ & $\begin{array}{c}\text { Total phenolic content mg/g } \\
(\mathrm{GAE})\end{array}$ \\
\hline Celtis africana & $835.59 \pm 1.56$ & $754 \pm 4.87$ & $98.7 \pm 2.43$ \\
Grosseria vignei & $825.10 \pm 4.11$ & $905.5 \pm 2.66$ & $108.5 \pm 2.79$ \\
Physalis micrantha & $800.9 \pm 4.34$ & $395 \pm 7.90$ & $15.26 \pm 09.10$ \\
Stachytarpheta & $836.8 \pm 5.57$ & $765 \pm 4.84$ & $72.1 \pm 1.47$ \\
angustifolia & $\mathrm{NA}$ & $36.34 \pm 1.06$ & NA \\
Ascorbic acid & & & \\
\hline
\end{tabular}

NA-not applicable.

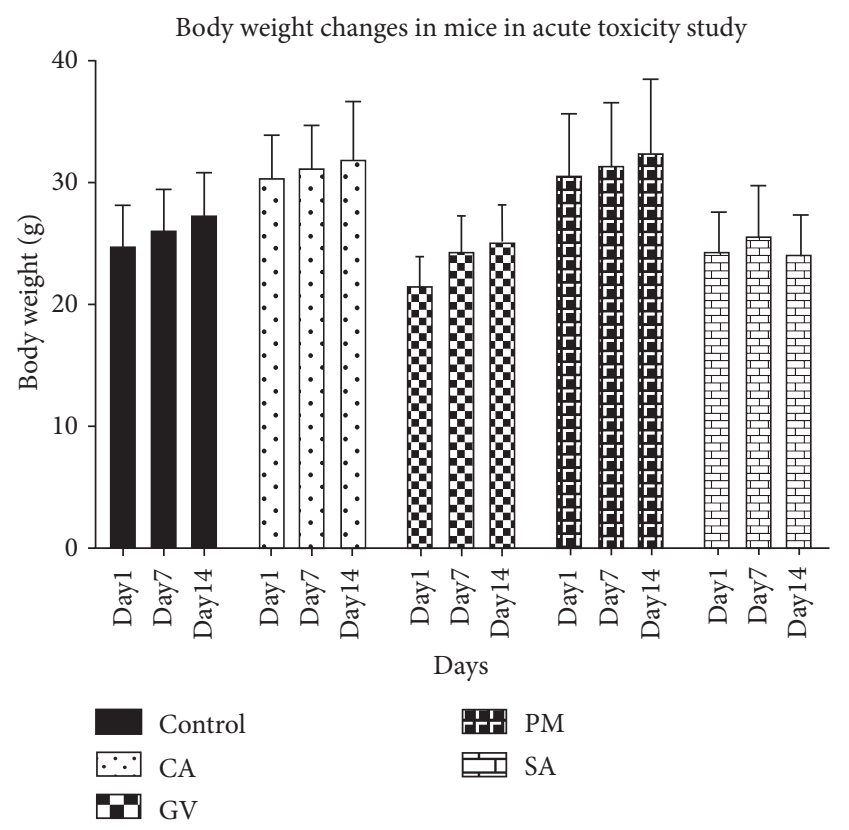

FIGURE 1: Body weight changes in mice in acute toxicity study. Each bar represents mean \pm SEM $(n=5)$. CA: Celtis africana, GV: Grosseria vignei, PM: Physalis micrantha, SA: Stachytarpheta angustifolia.

\section{Discussion}

The four medicinal plants used in this study are frequently used in various herbal preparations in Ghana. Ethanolic extracts of the various plants were obtained in yields comparable to other plant extraction experiments reported elsewhere $[25,27]$. Reports on several bioactivities of extracts from these plants are ubiquitous in the literature. These bioactivities include antimicrobial, anti-inflammatory, antioxidant, antidiabetic, neuropharmacological, laxative, antidiarrheal, gut, and immunomodulatory [27-33]. Despite widespread use in medicinal herbal formulations, very little information exists on the biological activities of extracts of Physalis micrantha. Extracts of Stachytarpheta angustifolia have been reported to possess antibacterial, antioxidant, immunomodulatory, and antidiabetic properties [30, 34]. Grosseria vignei has been shown to possess antioxidant and anti-inflammatory activities [29]. Interestingly, no detailed reports of the antiplasmodial activities of these plants exist in the literature, with the exception of Celtis africana. Crude solvent extracts of the leaf and stem of Celtis africana possess antiplasmodial activity against the Plasmodium falciparum parasite with an $\mathrm{IC}_{50}$ value of about $30 \mu \mathrm{g} / \mathrm{mL}[35,36]$. It has also been shown that the stem bark extract contains good antioxidant and anti-inflammatory compounds [27]. 


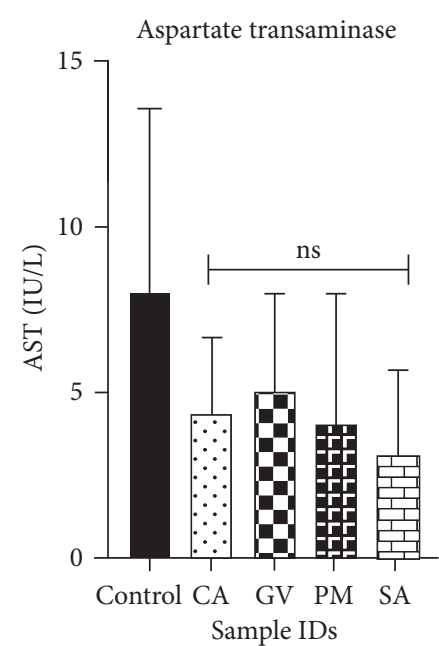

Control PH PM

$\because \mathrm{CA}$ SA 뵤 GV

(a)

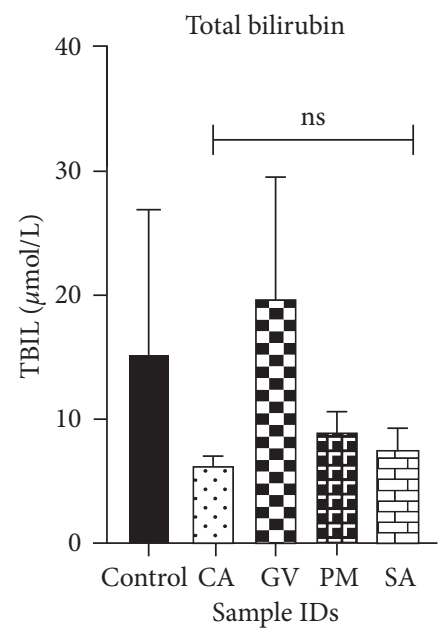

Control HFr PM

$\because$ CA 도 SA

E GV

(d)

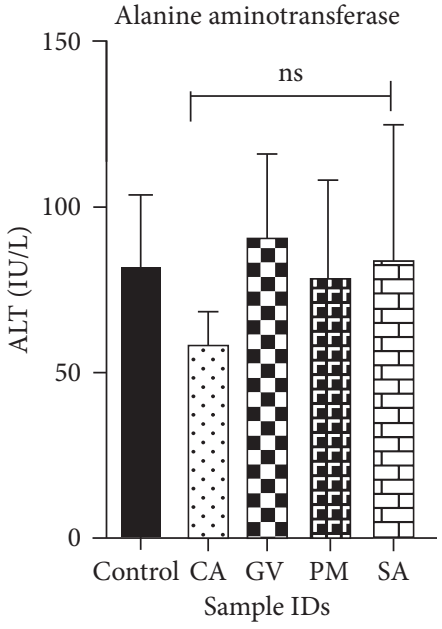

Control FPF PM

$\because \mathrm{CA}$ SA

므 $\mathrm{GV}$

(b)

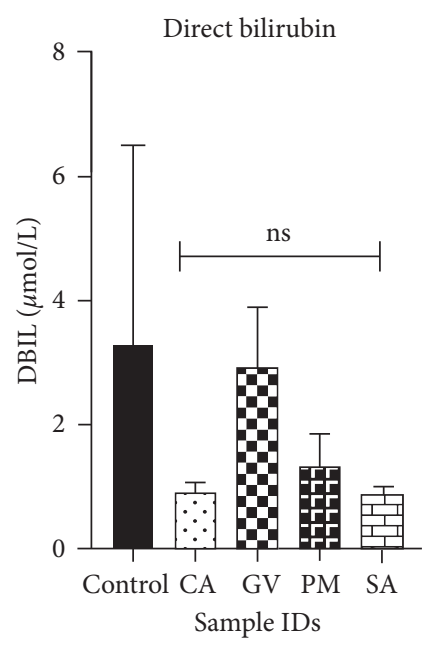

Control Frit PM

$\because \mathrm{CA}$ SA

마 GV

(e)

FIgure 2: Continued.

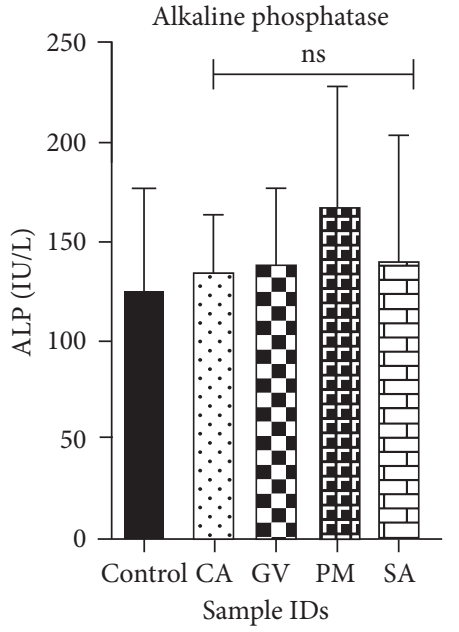

Control FFI PM

$\because \mathrm{CA}$ SA

EIV

(c)

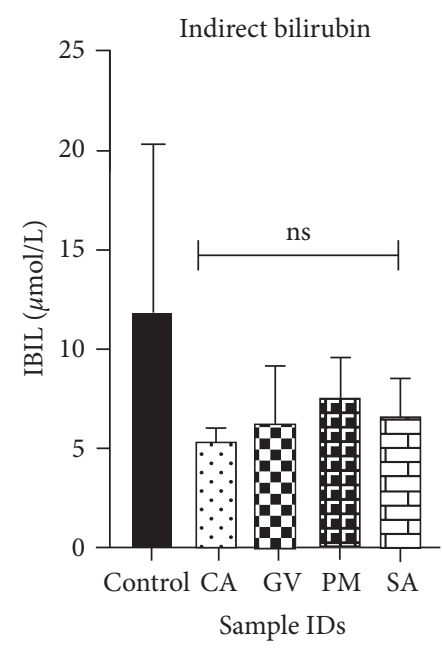

Control HFF PM

$\because \mathrm{CA}$ SA

E GV

(f) 


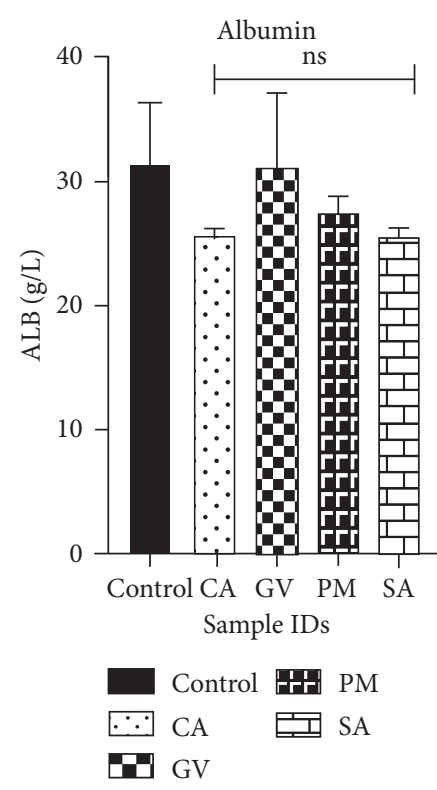

(g)

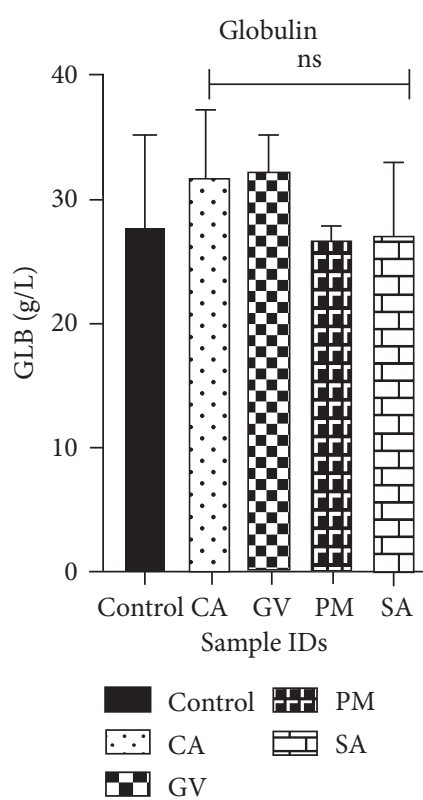

(h)

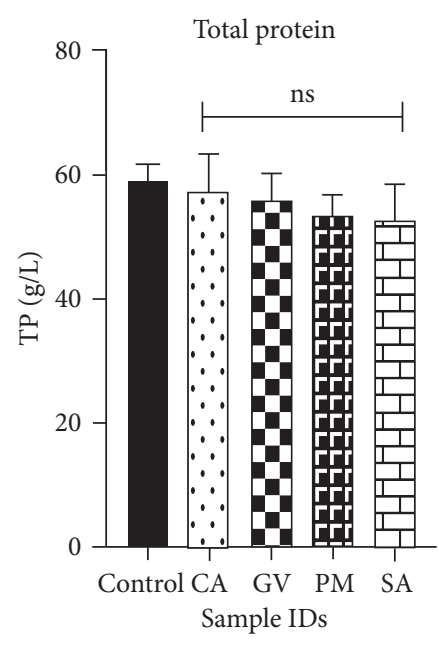

Control Prir PM

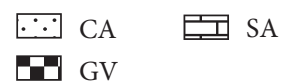

(i)

Figure 2: Effect of selected plant extracts on liver function profiles $(n=3)$. CA: Celtis africana, GV: Grosseria vignei, PM: Physalis micrantha, SA: Stachytarpheta angustifolia. (a) AST: aspartate transaminase, (b) ALT: alanine transaminase, (c) ALP: alkaline phosphatase, (d) TBIL: total bilirubin, (e) DBIL: direct bilirubin, (f) IBIL: indirect bilirubin, (g) ALB: albumin, (h) GLB; globulin, and (i) TP: total protein. Each bar represents mean \pm SEM $(n=3)$. $p<0.05$ was considered to be statistically significant (one-way analysis of variance (ANOVA) followed by Dunnett's post hoc test).

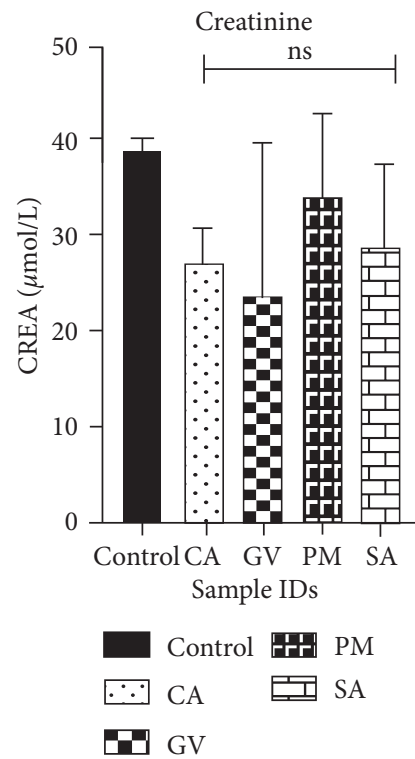

(a)

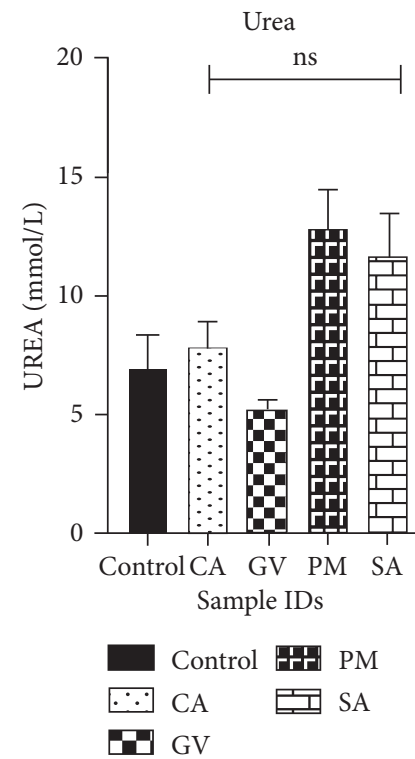

(b)

Figure 3: Effect of selected plant extracts on kidney function profile $(n=3)$. CA: Celtis africana, GV: Grosseria vignei, PM: Physalis micrantha, SA: Stachytarpheta angustifolia. (a) CREA: creatinine and (b) UREA: urea. Each bar represents mean $\pm \operatorname{SEM}(n=3)$. $p<0.05$ was considered to be statistically significant (one-way analysis of variance (ANOVA) followed by Dunnett's post hoc test).

Various classes of phytochemicals have been shown to possess interesting antiplasmodial properties. These include alkaloids, terpenes, flavonoids, limonoids, chalcones, and coumarins [37]. Flavonoids and tannins were present in all plant extracts studied (Table 3) and these phytochemicals probably play key roles in the biological activity of these plant extracts. In the antiplasmodial activity test, extracts of Physalis micrantha and Celtis africana were found to have 
high and moderate activity against the Plasmodium falciparum parasite with $\mathrm{IC}_{50}$ values of 3.51 and $29.05 \pm 1.29 \mu \mathrm{g} /$ $\mathrm{mL}$, respectively (Table 2 ). The $\mathrm{IC}_{50}$ value obtained in this work for Celtis africana is very similar to other reports on its antiplasmodial activity $[35,36]$. These $\mathrm{IC}_{50}$ values are an indication of good antiplasmodial activity of the two plant extracts and partly provide scientific backing for their use in local herbal preparations for malaria treatment. The low $\mathrm{IC}_{50}$ values recorded for extracts of Physalis micrantha and Celtis africana are probably as a result of the synergistic action of one or more of the phytochemical constituents present in these plant extracts, as reported by other works [38, 39]. Flavonoids, in general, have been reported as potent secondary metabolites of plants possessing broad spectrum biological activities [37, 40]. Grosseria vignei and Stachytarpheta angustifolia were classified as being inactive in the antiplasmodial assay due to their high $\mathrm{IC}_{50}$ values $(>50 \mu \mathrm{g} /$ $\mathrm{mL}$ ). For this study, the ring stage of the Plasmodium falciparum parasite was used. It is possible that Grosseria vignei and Stachytarpheta angustifolia extracts have little to no effect on the parasite at this stage but may inhibit other stages of the parasite. It is also known that some extracts without in vitro antiplasmodial activities may possess remarkable in vivo activity - via stimulating of immune responses. Extracts of Markhamia lutea were active against Plasmodium berghei in vivo even though they were inactive in in vitro assays [32]. Some of the extracts used in this study may fall within this category. Additionally, most herbal preparations are a combination of two or more plants [18]. Synergistic action is thus expected in such situations.

Reactive oxygen and nitrogen species are major factors in the induction of oxidative stress in cells. These species have been suggested to play important roles in systemic complications that occur during malaria infection. During malaria infection, hydroxyl radicals are produced in the liver and these radicals contribute significantly to the induction of cellular oxidative stress. It has also been shown that normal red blood cells produce about 50\% fewer hydroxyl radicals and hydrogen peroxide than Plasmodium falciparum-infected red blood cells [41]. Additionally, FP presence in the host cell contributes to oxidative imbalance [13]. Together, this set of data points to an important role of reactive species during malaria infection. This necessitated the investigation of the antioxidant activities of the plant extracts. All extracts displayed very high activities in the phosphomolybdenum test, with total antioxidant capacities greater than $800 \mathrm{mg} / \mathrm{g}$ AAE. In the DPPH radical scavenging assay, the extracts showed good activities as well. There was a good agreement between the DPPH radical scavenging results and the antiplasmodial assay results. Extracts of Physalis micrantha displayed the best DPPH scavenging ability. Interestingly, this same extract showed very high antiplasmodial activity. It is thus possible that the extract exerts its antiplasmodial activity by contributing to oxidative balance in an infected cell. Phenolic compounds have been suggested as an important class that mops up free radicals [42]. However, there is no agreement about the correlation between antioxidant activity and TPC. In this study, no direct correlation was observed between TPC and antioxidant activities.

In the acute toxicity studies, no mortality was recorded in any of the extract-treatment groups at the maximum dose of $2000 \mathrm{mg} / \mathrm{kg}$ of extract administered. A single high dose is recommended for the evaluation of acute toxicity [24]. All behavioral and morphological observations made in all treatment and control groups were also normal. Therefore, the $\mathrm{LD}_{50}$ (median lethal dose) of all extracts was estimated to be greater than $2000 \mathrm{mg} / \mathrm{kg}$ [24], and as such, all extracts are rated as safe up to this dosage level. Change in body weight of experimental animals is frequently used as an index of toxicity, as it is simple yet very sensitive $[43,44]$. An increase in body weight was observed for animals in the control group as well as treatment groups that received Physalis micrantha, Celtis africana, and Grosseria vignei. Animals in the group that received Stachytarpheta angustifolia extract experienced a marginal reduction in body weight over the 14-day experimental period. However, there was no significant change $(p>0.05)$ in body weight in animals in that group from days 1 to 14 .

Medicinal plants with a history of long usage in the treatment of diseases are usually perceived to be safe. Contrary to this notion, there have been a number of reports in the recent literature that reports on adverse effects of plant extracts on the liver and kidneys $[17,45]$. Metabolic defects and injuries to these organs can be deduced from changes in the levels and activities of key biomarkers. Aspartate transaminase, alanine transaminase, alkaline phosphatase, total bilirubin, direct bilirubin, indirect bilirubin, albumin, globulin, and total protein are biomarkers of liver function and changes in their levels and/or activities are indicative of toxicity. In this study, no significant differences $(p>0.05)$ were observed in the levels of the markers in the control group and the extract-treatment groups. In the kidney function test, the levels of creatinine and urea were used to evaluate toxicity to the kidney. Similar to results in the liver function test, no significant differences were observed between animals that received the vehicle and those that received the extracts. Thus, it can be deduced that the extracts at $2000 \mathrm{mg} / \mathrm{kg}$ posed no adverse effect to the proper functioning of the liver and kidney and are safe at doses at or below this concentration.

\section{Conclusion}

Extracts of Physalis micrantha and Celtis africana possessed very good antiplasmodial activities. On the other hand, extracts of Grosseria vignei and Stachytarpheta angustifolia displayed no activity towards the Plasmodium falciparum strain used in the study. All extracts showed great potential in mopping up reactive species, as evidenced by their strong antioxidant activities. All extracts were safe at doses at/or below $2000 \mathrm{mg} / \mathrm{kg}$. The results of this study provide important information about the antiplasmodial and antioxidant activities of the plant extracts and partly provide some scientific basis for their use in folkloric medicine. 


\section{Data Availability}

All data generated or analyzed during this study are included in this published article.

\section{Ethical Approval}

The project proposal and procedures were reviewed and approved by the Institution Ethics Review Board for Animal Use at the Kwame Nkrumah University of Science and Technology, Kumasi, Ghana.

\section{Conflicts of Interest}

The authors declare no conflicts of interest.

\section{Authors' Contributions}

The study was conceived by LSB. Experiments were designed by LSB and MKL. All experiments were carried out by MKL. Data were analyzed by MKL with support from LSB. All authors read and approved the final manuscript.

\section{Acknowledgments}

The authors are grateful to the Central Laboratory and the Departments of Chemistry and Pharmacology (all KNUST) for permitting this study to be carried out at their facilities. Funding for this work was provided by an International Foundation for Science (IFS) Collaborative Research Grant to LSB.

\section{References}

[1] World Health Organization, World Malaria Report 2019, World Health Organization, Geneva, Switzerland, 2019.

[2] J. Hemingway, R. Shretta, T. N. Wells et al., "Tools and strategies for malaria control and elimination: what do we need to achieve a grand convergence in malaria?" PLoS Biology, vol. 14, no. 3, Article ID e1002380, 2016.

[3] R. T. Eastman and D. A. Fidock, "Artemisinin-based combination therapies: a vital tool in efforts to eliminate malaria," Nature Reviews Microbiology, vol. 7, no. 12, pp. 864-874, 2009.

[4] World Health Organization, "Malaria vaccine: WHO position paper, January 2016-recommendations," Vaccine, vol. 36, no. 25, pp. 3576-3577, 2018.

[5] V. S. Moorthy and J.-M. Okwo-Bele, "Final results from a pivotal phase 3 malaria vaccine trial," The Lancet, vol. 386, no. 9988 , pp. 5-7, 2015.

[6] A. M. Dondorp, S. Yeung, L. White et al., "Artemisinin resistance: current status and scenarios for containment," Nature Reviews Microbiology, vol. 8, no. 4, pp. 272-280, 2010.

[7] E. A. Ashley, M. Dhorda, R. M. Fairhurst et al., "Spread of artemisinin resistance in plasmodium falciparum malaria," The New England Journal of Medicine, vol. 371, no. 5, pp. 411-423, 2014.

[8] O. Famin, M. Krugliak, and H. Ginsburg, "Kinetics of inhibition of glutathione-mediated degradation of ferriprotoporphyrin IX by antimalarial drugs," Biochemical Pharmacology, vol. 58, no. 1, pp. 59-68, 1999.

[9] O. Famin and H. Ginsburg, "The treatment of plasmodium falciparum-infected erythrocytes with chloroquine leads to accumulation of ferriprotoporphyrin IX bound to particular parasite proteins and to the inhibition of the parasite's 6phosphogluconate dehydrogenase," Parasite, vol. 10, no. 1, pp. 39-50, 2003.

[10] T. J. Egan, J. M. Combrinck, J. Egan et al., "Fate of haem iron in the malaria parasite plasmodium falciparum," Biochemical Journal, vol. 365, no. 2, pp. 343-347, 2002.

[11] N. Campanale, C. Nickel, C. A. Daubenberger et al., "Identification and characterization of heme-interacting proteins in the malaria parasite, plasmodium falciparum," Journal of Biological Chemistry, vol. 278, no. 30, pp. 27354-27361, 2003.

[12] L. Tilley, P. Loria, and M. Foley, "Chloroquine and other quinoline antimalarials," in Antimalarial Chemotherapy, pp. 87-121, Springer, Cham, Switzerland, 2001.

[13] K. Becker, L. Tilley, J. L. Vennerstrom, D. Roberts, S. Rogerson, and H. Ginsburg, "Oxidative stress in malaria parasite-infected erythrocytes: host-parasite interactions," International Journal for Parasitology, vol. 34, no. 2, pp. 163-189, 2004.

[14] World Health Organization, National Policy on Traditional Medicine and Regulation of Herbal Medicines: Report of a WHO Global Survey, World Health Organization, Geneva, Switzerland, 2005.

[15] D. A. van Schalkwyk, History of Antimalarial Agents, John Wiley \& Sons, New York, NY, USA, 2015.

[16] M. Angell and J. P. Kassirer, "Alternative medicine-the risks of untested and unregulated remedies," The New England Journal of Medicine, vol. 339, no. 12, pp. 839-841, 1998.

[17] C. W. Fennell, K. L. Lindsey, L. J. McGaw et al., "Assessing African medicinal plants for efficacy and safety: pharmacological screening and toxicology," Journal of Ethnopharmacology, vol. 94, no. 2-3, pp. 205-217, 2004.

[18] A. Asase, A. A. Oteng-Yeboah, G. T. Odamtten, and M. S. Simmonds, "Ethnobotanical study of some Ghanaian anti-malarial plants," Journal of Ethnopharmacology, vol. 99, no. 2, pp. 273-279, 2005.

[19] G. Afu, M. K. Laryea, and L. S. Borquaye, "Biological efficacy and toxicological evaluation of ethanolic extract of cassia nodosa buch.-ham. (leguminosae)," Journal of Chemistry, vol. 2020, Article ID 3983491, 13 pages, 2020.

[20] W. C. Evans, "Trease and evans pharmacognosy," International Edition E-Book, Elsevier Health Sciences, Berlin, Germany, 2009.

[21] W. Trager, "The cultivation of plasmodium falciparum: applications in basic and applied research on malaria," Annals of Tropical Medicine \& Parasitology, vol. 81, no. 5, pp. 511-529, 1987.

[22] A. G. Maier and M. Rug, "In vitro culturing plasmodium falciparum erythrocytic stages," in Malaria, pp. 3-15, Springer, Cham, Switzerland, 2012.

[23] J. N. Gyesi, R. Opoku, and L. S. Borquaye, "Chemical composition, total phenolic content, and antioxidant activities of the essential oils of the leaves and fruit pulp of Annona muricata L. (soursop) from Ghana," Biochemistry Research International, vol. 2019, Article ID 4164576, 9 pages, 2019.

[24] Organization of Economic Co-operation and Development (OECD), “Test no. 425: acute oral toxicity: up-and-down procedure," Organization of Economic Co-operation and Development (OECD), Paris, France, 425, 2008.

[25] M. K. Laryea and L. S. Borquaye, "Antimalarial efficacy and toxicological assessment of extracts of some Ghanaian medicinal plants," Journal of Parasitology Research, vol. 2019, Article ID 1630405, 9 pages, 2019. 
[26] M. C. Jonville, H. Kodja, L. Humeau et al., "Screening of medicinal plants from reunion Island for antimalarial and cytotoxic activity," Journal of Ethnopharmacology, vol. 120, no. 3, pp. 382-386, 2008.

[27] L. S. Borquaye, S. A. Saah, D. Adu-Poku, L. Adu-Gyamfi, K. Bitian, and W. Bambil, "Anti-inflammatory, antioxidant and total phenolic content of the ethanolic extracts of Celtis africana Burm. f," Current Science Perspectives, vol. 6, no. 3, pp. 43-49, 2020.

[28] A. M. Al-Taweel, S. Perveen, A. M. El-Shafae et al., "Bioactive phenolic amides from Celtis africana," Molecules, vol. 17, no. 3, pp. 2675-2682, 2012.

[29] L. S. Borquaye, M. K. Laryea, E. N. Gasu et al., "Anti-inflammatory and antioxidant activities of extracts of Reissantia indica, Cissus cornifolia and Grosseria vignei," Cogent Biology, vol. 6, no. 1, Article ID 1785755, 2020.

[30] A. B. Isah, Y. K. E. Ibrahim, E. M. Abdulrahman, and M. A. Ibrahim, "The hypoglycaemic activity of the aqueous extract of Stachytarpheta angustifolia (verbanaceae) in normoglycaemic and alloxan-induced diabetic rats," Pakistan Journal of Biological Sciences PJBS, vol. 10, no. 1, pp. 137-141, 2007.

[31] A. Khan, N. ur-Rehman, A. M. Al-Taweel, S. Perveen, G. A. Fawzy, and A.-H. Gilani, "Studies on prokinetic, laxative, antidiarrheal and gut modulatory activities of the aqueous-methanol extract of Celtis africana and Underlying Mechanisms," International Journal of Pharmacology, vol. 8, no. 8, pp. 701-707, 2012.

[32] E. Hakizamungu and M. Weri, "Usage of medicinal plants in the treatment of malaria in the traditional medicine of Rwanda," Bull Med Trad Pharm, vol. 2, no. 1, pp. 11-17, 1988.

[33] K. I. Tapfuma, E. K. Nchabeleng, O. A. Adebo et al., "Antibacterial activity and gas chromatography mass spectrometry (GC-MS)-based metabolite profiles of Celtis africana and its endophytic extracts," Industrial Crops and Products, vol. 157, Article ID 112933, 2020.

[34] F. M. Awah, P. N. Uzoegwu, J. O. Oyugi et al., "Free radical scavenging activity and immunomodulatory effect of Stachytarpheta angustifolia leaf extract," Food Chemistry, vol. 119, no. 4, pp. 1409-1416, 2010.

[35] N. M. Al-Musayeib, R. A. Mothana, S. Al-Massarani, A. Matheeussen, P. Cos, and L. Maes, "Study of the in vitro antiplasmodial, antileishmanial and antitrypanosomal activities of medicinal plants from Saudi Arabia," Molecules, vol. 17, no. 10, pp. 11379-11390, 2012.

[36] D. Lacroix, S. Prado, D. Kamoga et al., "Antiplasmodial and cytotoxic activities of medicinal plants traditionally used in the village of Kiohima, Uganda," Journal of Ethnopharmacology, vol. 133, no. 2, pp. 850-855, 2011.

[37] S. Schwikkard and F. R. v. Heerden, "Antimalarial activity of plant metabolites," Natural Product Reports, vol. 19, no. 6, pp. 675-692, 2002.

[38] S. Ravikumar, S. Jacob Inbaneson, P. Suganthi, M. Venkatesan, and A. Ramu, "Mangrove plants as a source of lead compounds for the development of new antiplasmodial drugs from south east coast of India," Parasitology Research, vol. 108, no. 6, pp. 1405-1410, 2011.

[39] P. V. V. Satish and K. Sunita, "Antimalarial efficacy of Pongamia pinnata (L) pierre against Plasmodium falciparum (3D7 strain) and Plasmodium berghei (ANKA)," BMC Complementary Medicine and Therapies, vol. 17, no. 1, p. 458, 2017.
[40] S. Saxena, N. Pant, D. C. Jain, and R. S. Bhakuni, "Antimalarial agents from plant sources," Current Science, vol. 85, no. 9, pp. 1314-1329, 2003.

[41] S. Percário, D. R. Moreira, B. A. Q. Gomes et al., "Oxidative stress in malaria," International Journal of Molecular Sciences, vol. 13, no. 12, pp. 16346-16372, 2012.

[42] R. Amorati, M. C. Foti, and L. Valgimigli, "Antioxidant activity of essential oils," Journal of Agricultural and Food Chemistry, vol. 61, no. 46, pp. 10835-10847, 2013.

[43] A. Nardos and E. Makonnen, "In vivo antiplasmodial activity and toxicological assessment of hydroethanolic crude extract of Ajuga remota," Malaria Journal, vol. 16, no. 1, p. 25, 2017.

[44] F. Ayisi, C. N. Mensah, and L. S. Borquaye, "Antiplasmodial potential and safety evaluation of the ethanolic stem bark extract of Distemonanthus benthamianus baill. (Leguminosae)," Scientific African, vol. 12, Article ID e00809, 2021.

[45] C. Liu, H. Fan, Y. Li, and X. Xiao, "Research advances on hepatotoxicity of herbal medicines in China," BioMed Research International, vol. 2016, Article ID 7150391, 14 pages, 2016. 